\title{
Performance of New Sugarcane Varieties in the Coastal and Inner Plains of Eastern Puerto Rico ${ }^{1}$
}

\author{
T. L. Chu, E. Alsina, J. L. Serapión, J. L. Rodriguez, and C. L. \\ González-Molina ${ }^{2}$
}

ABSTRACT

A total of 37 new sugarcane clones were lested in four replicated yield trials in the coastal and inner plains of eastern Puerto Rico during the period 197377. Results obtained from plant cane and the following two ratoon crops were encouraging. It was found that three clones (PR 67-1070, PR 67-3129, and PR 67-245) are highly promising for the humid Humacao-Yabucoa area. PR 671070 appears to be the variety most adapted to well-drained soils with high permeability. PR 67-3129 and PR 67-245, on the contrary, seem better adapted to soils with high water-holding capacity and high fertility. Efforts were also made to determine the relative maturity-pattern for the three clones together with the existing commercial varieties in the area. Appropriate harvest schedules for these varieties are discussed.

\section{INTRODUCTION}

Although the sugarcane breeding program in Puerto Rico was initiated in 1910, only two island-bred varieties, M 336 and PR 980, had attained a substantial cane acreage prior to 1960. As time went on, it became increasingly evident that a major intensification of the breeding effort was necessary. During the early 1960s steps were taken to broaden the genetic base, to expand seedling populations, and to establish an islandwide evaluation and testing program.

At present, some 7,500 acres encompassing the coastal and inner plains of the Humacao-Yabucoa area are planted in sugarcane. The major soil types are classified as Mabi clay, a fine, montmorillonitic, isohyperthermic, Vertic Eutropepts; Maunabo clay, a fine, mixed, acid, isohyperthermic, Typic Tropaquepts; Coloso silt clay, a fine, mixed, nonacid, isohyperthermic, Aeric Tropic Fluvaquents; and Viví loam, a member of a coarse-loamy, mixed, isohyperthermic family of Fluventic Hapludolls. ${ }^{3}$ Each of the clay soils is characterized by high natural fertility, high available water capacity, and somewhat poor drainage. Vivi loam, on the

${ }^{1}$ Manuscript submitted to Editorial Board June 20, 1978.

${ }^{2}$ Plant Breeder, Associate Agronomist, Assistant Agronomists, Plant Breeder and Professor, respectively, Agricultural Experiment Station, Mayagüez Campus, University of Puerto Rico, Río Piedras, P. R. The authors wish to express their appreciation to Messrs. S. O. Vélez, former Research Assistant, and E. Ojeda Peña, Technical Aid, for their participation in a part of the field operation of the experiments.

"M. A. Lugo-López and Luis H. Rivera, Updated Taxonomic Classification of the Soils of Puerto Rico, Agri. Exp. Stn. Univ. P.R. Bull. 258, December, 1977. 
contrary, is highly permeable and well drained. ${ }^{4}$ Although a humid climate prevails in this section of Puerto Rico, an uneven rainfall distribution plus the lack of irrigation facilities often results in yield losses owing to drought conditions during the first half of the year.

The current leading commercial varieties for the sugarcane areas of Fajardo-Naguabo, Humacao, and Yabucoa are PR 980, H 32-8560, and PR 1059, respectively. PR 980 is generally characterized by high yields but low juice quality, particularly on poorly drained soils. H 32-8560 has good juice quality but poor ratooning ability. PR 1059, perhaps the sweetest commercial variety on the island, tends to yield poor tonnages, especially in the ratoon crops. The present report deals with the performance of certain hybrid varieties resulting from an intensified breeding effort since the mid-1960s.

\section{MATERIALS AND METHODS}

A total of 37 new sugarcane clones were tested in four replicated yield trials from November 1973 to April 1977. All clones received preliminary screening against mosaic disease. The test-sites, field designs, soil types, number of clones tested, time of planting and harvesting, and the standard variety used in each experiment are compiled in table 1. Experimental plots consisted of three rows 5.5-foot on center and 40 feet long. All experiments were cut by hand. The cane was weighed with a tractormounted hydraulic loader and scale. The field management for each experiment was in accordance with local cultural practices.

In addition to the sucrose-percent-cane, tons of cane, and tons of sugar per acre, some relevant agronomic characteristics such as germination, tillering, stalk thickness and length, drought resistance, lodging resistance, and flowering were also carefully evaluated by visual rating on a 15 scale for the plant cane and the following two ratoon crops (table 2). The sucrose-percent-cane of 10 stalk-samples per plot of each tested clone in the yield trials was obtained by the pol-ratio method. Tonnage and sugar yield data for each crop and for combined three crops by site were subjected to statistical analysis.

There is an urgent need in Puerto Rico for sugarcane varieties that produce high quality cane throughout the harvest season. For this reason the relative maturity-patterns of new clones and existing commercial varieties were determined at two sites, Mayo Farm and Isleta Farm. These patterns were obtained by measuring the sucrose-percent-cane of whole stalk samples harvested at five monthly intervals. Samples consisting of 20 whole stalks and composited of three sub-samples were taken

${ }^{4}$ Rafael A. Boccheciamp, et al., Soil survey of the Humacao area of eastern Puerto Rico, Soil Cons. Serv., USDA, January 1977. 
TABLE 1.-Test-sites, field designs, soil types, number of clones tested, time of planting and harvesting, and the standard variety used in each of 4 yield trials

\begin{tabular}{|c|c|c|c|c|c|c|}
\hline Test-site & Crop & Field design & Soil type & $\begin{array}{c}\text { No. clones } \\
\text { tested }\end{array}$ & $\begin{array}{l}\text { Time of planting } \\
\text { and harvesting }\end{array}$ & Standard variety \\
\hline Exp. Stn., Gurabo & $\begin{array}{l}\text { Plant cane } \\
\text { 1st. ratoon } \\
\text { 2nd. ratoon }\end{array}$ & $\mathrm{PBIB}^{1}$ with 6 replicates & Mabi clay & 18 & $\begin{array}{l}\text { Nov., } 1973 \\
\text { Mar., } 1975 \\
\text { Mar., } 1975 \\
\text { Mar., } 1976 \\
\text { Mar., } 1976 \\
\text { Mar., } 1977\end{array}$ & PR 1059 \\
\hline Junio Farm, Humacao & $\begin{array}{l}\text { Plant cane } \\
\text { 1st. ratoon } \\
\text { 2nd. ratoon }\end{array}$ & $\begin{array}{l}5 \times 5 \mathrm{BL}^{2} \text { with } 6 \text { repli- } \\
\text { cates }\end{array}$ & Maunabo clay & 25 & $\begin{array}{l}\text { Nov., } 1973 \\
\text { Mar., } 1975 \\
\text { Mar., } 1975 \\
\text { Mar., } 1976 \\
\text { Mar., } 1976 \\
\text { Jan., } 1977\end{array}$ & PR 980 \\
\hline Mayo Farm, Humacao & $\begin{array}{l}\text { Plant cane } \\
\text { 1st ratoon } \\
\text { 2nd. ratoon }\end{array}$ & $\begin{array}{l}4 \times 5 \mathrm{RL}^{3} \text { with } 6 \text { repli- } \\
\text { cates }\end{array}$ & Mabí clay & 20 & $\begin{array}{l}\text { Dec., } 1973 \\
\text { Mar., } 1975 \\
\text { Mar., } 1975 \\
\text { Apr., } 1976 \\
\text { Apr., } 1976 \\
\text { Feb., } 1977\end{array}$ & H $32-8560$ \\
\hline Unión Farm, Yabucoa & $\begin{array}{l}\text { Plant cane } \\
\text { 1st. ratoon } \\
\text { 2nd. ratoon }\end{array}$ & PBIB' with 6 replicates & Viví loam & 20 & $\begin{array}{l}\text { Nov., } 1973 \\
\text { Apr., } 1975 \\
\text { Apr., } 1975 \\
\text { Mar., } 1976 \\
\text { Mar., } 1976 \\
\text { Mar., } 1977\end{array}$ & PR 1059 \\
\hline
\end{tabular}

${ }^{1}$ Partially balanced incomplete blocks.

${ }^{2} 5 \times 5$ balanced lattice.

${ }^{3} 4 \times 5$ rectangular lattice. 
TABLE 2.-Variety performance on germination, tillering, stalk thickness and length, drought resistance, lodging resistance, and flowering rated on the plant cane and following two ratoon crops at four test-sites

\begin{tabular}{|c|c|c|c|c|c|c|c|}
\hline \multirow[b]{2}{*}{ Variety } & \multirow[b]{2}{*}{$\begin{array}{l}\text { Germi- } \\
\text { nation }\end{array}$} & \multirow{2}{*}{$\begin{array}{c}\text { Til- } \\
\text { lering }\end{array}$} & \multicolumn{2}{|c|}{ Stalk } & \multirow[b]{2}{*}{$\begin{array}{l}\text { Drought } \\
\text { resistance }\end{array}$} & \multirow[b]{2}{*}{$\begin{array}{l}\text { Lodging } \\
\text { resistance }\end{array}$} & \multirow{2}{*}{$\begin{array}{l}\text { Flower } \\
\text { ing }\end{array}$} \\
\hline & & & $\begin{array}{l}\text { thick- } \\
\text { ness }\end{array}$ & length & & & \\
\hline PR 63-192 & $3^{1}$ & $2^{1}$ & $3^{2}$ & $3^{3}$ & $3^{4}$ & $1^{4}$ & $1^{5}$ \\
\hline PR 64-610 & 3 & 3 & 2 & 3 & 4 & 4 & 3 \\
\hline PR 64-1618 & 2 & 2 & 3 & 2 & 2 & 2 & 3 \\
\hline PR 67-245 & 3 & 2 & 2 & 3 & 3 & 1 & 2 \\
\hline PR 67-1070 & 2 & 3 & 2 & 2 & 2 & 2 & 2 \\
\hline PR 67-3073 & 3 & 3 & 1 & 2 & 3 & 4 & 2 \\
\hline PR 67-3129 & 2 & 2 & 3 & 3 & 3 & 2 & 3 \\
\hline PR 67-3210 & 2 & 2 & 4 & 4 & 4 & 1 & 2 \\
\hline H $32-8560$ & 3 & 3 & 2 & 2 & 3 & 4 & 4 \\
\hline PR 980 & 2 & 2 & 3 & 2 & 2 & 3 & 4 \\
\hline PR 1059 & 3 & 2 & 4 & 4 & 4 & 1 & 2 \\
\hline
\end{tabular}

${ }^{1} 1$ denotes very good; 5 very poor.

${ }^{2} 1$ denotes very thick; 5 very thin.

${ }^{3} 1$ denotes very tall; 5 very short.

${ }^{4} 1$ denotes highly resistant; 5 highly suceptible.

"I 1 denotes nil; 5 very heavy.

at random from each row of the three-row plots. The first samples were taken when the cane was approximately 12 months of age.

\section{RESULTS}

In order to make an area-wide evaluation possible only the clones that appeared, at least in two trials, with good performance are compiled by site (table 3). Visual ratings for relevant agronomic characters are presented in table 2 . The relative maturity-patterns for promising new clones and the existing commercial varieties are illustrated in figures 1 and 2 .

In Gurabo, as indicated in table 3, no significant difference in TSA for the combined analysis of three crops was observed between any two varieties. Variety PR 67-3129, however, produced significantly more cane per acre than PR 67-3210, PR 64-610, and PR 1059, and more sugar per acre than PR 1059 in the second ratoon crop.

Data from Junio Farm at Humacao revealed that the three varieties, PR 67-3129, PR 64-1618, and PR 67-245, produced more sugar per acre than the standard commercial variety PR 980 . They outyielded PR 980 by values of $22.8,21.2$, and $20.9 \%$, respectively. All differences were statistically significant.

TSA data obtained from Mayo Farm, Humacao (table 3) indicated that varieties PR 67-3210 and PR 67-3129 produced significantly more 
TABLE 3.-Mean yields for sucrose percent, tons of cane, and tons of sugar per acre obtained from three crops in each of four yield trials conducted in the eastern section of Puerto Rico

\begin{tabular}{|c|c|c|c|c|c|c|c|c|c|c|c|c|c|}
\hline \multirow{2}{*}{ Variety } & \multicolumn{3}{|c|}{ Plant cane } & \multicolumn{3}{|c|}{ First ratoon } & \multicolumn{3}{|c|}{ Second ratoon } & \multicolumn{3}{|c|}{$\begin{array}{c}\text { Combined analysis } \\
\text { of } 3 \text { crops }\end{array}$} & \multirow{2}{*}{$\begin{array}{l}\text { Index of TSA } \\
\text { compared with } \\
\text { standard variety }\end{array}$} \\
\hline & Sucrose & $\mathrm{TCA}^{1}$ & $\mathrm{TSA}^{2}$ & Sucrose & $\mathrm{TCA}^{\prime}$ & $\mathrm{TSA}^{2}$ & Sucrose & $\mathrm{TCA}^{1}$ & $\mathrm{TSA}^{2}$ & Sucrose & $\mathrm{TCA}^{\prime}$ & $\overline{\mathrm{TSA}^{2}}$ & \\
\hline & $\%$ & & & $\%$ & & & $\%$ & & & $\%$ & & & $\%$ \\
\hline \multicolumn{14}{|c|}{ Experimental Station, Gurabo } \\
\hline PR 64-610 & $13.36 \mathrm{a}^{3}$ & $65.7 \mathrm{a}$ & $8.77 \mathrm{a}$ & $13.82 \mathrm{a}$ & $52.7 \mathrm{a}$ & $7.29 \mathrm{a}$ & $12.19 \mathrm{a}$ & $33.6 \mathrm{~cd}$ & $4.03 \mathrm{bc}$ & $13.12 \mathrm{a}$ & $50.7 \mathrm{a}$ & $6.69 a$ & 116.8 \\
\hline PR 67-3129 & $13.35 \mathrm{a}$ & $56.8 \mathrm{a}$ & $7.58 \mathrm{a}$ & $11.41 \mathrm{~b}$ & $56.3 a$ & $6.39 \mathrm{a}$ & $11.80 \mathrm{a}$ & $49.9 \mathrm{ab}$ & $5.93 \mathrm{ab}$ & $12.19 \mathrm{a}$ & $54.3 \mathrm{a}$ & $6.64 \mathrm{a}$ & 116.1 \\
\hline PR 67-1070 & $14.94 \mathrm{a}$ & $53.8 \mathrm{a}$ & $8.06 \mathrm{a}$ & $11.60 \mathrm{~b}$ & $53.0 \mathrm{a}$ & $6.15 \mathrm{a}$ & $12.32 \mathrm{a}$ & $41.9 \mathrm{bc}$ & $5.26 \mathrm{abc}$ & $12.95 \mathrm{a}$ & $49.9 \mathrm{a}$ & $6.49 \mathrm{a}$ & 113.5 \\
\hline PR $67-3210$ & $13.22 \mathrm{a}$ & $53.7 \mathrm{a}$ & $7.11 \mathrm{a}$ & $12.70 \mathrm{ab}$ & $47.9 \mathrm{a}$ & $6.00 \mathrm{a}$ & $12.42 \mathrm{a}$ & $34.9 \mathrm{~cd}$ & $4.28 \mathrm{bc}$ & $12.78 \mathrm{a}$ & $45.5 \mathrm{a}$ & $5.80 \mathrm{a}$ & 101.4 \\
\hline PR 1059 & $14.13 \mathrm{a}$ & $50.5 a$ & $7.15 \mathrm{a}$ & $12.88 \mathrm{ab}$ & $48.2 \mathrm{a}$ & $6.22 \mathrm{a}$ & $11.54 \mathrm{a}$ & $32.8 \mathrm{~d}$ & $3.79 \mathrm{c}$ & $12.85 a$ & $43.8 \mathrm{a}$ & $5.72 \mathrm{a}$ & 100.0 \\
\hline \multicolumn{14}{|c|}{ Junio Farm, Humacao } \\
\hline PR 67-3129 & $12.08 \mathrm{a}$ & $29.5 \mathrm{ab}$ & $3.60 \mathrm{a}$ & $11.62 \mathrm{ab}$ & $43.0 \mathrm{ab}$ & $4.97 \mathrm{a}$ & $11.22 \mathrm{ab}$ & $47.4 \mathrm{a}$ & $5.35 \mathrm{a}$ & $11.63 \mathrm{ab}$ & $39.9 \mathrm{a}$ & $4.63 \mathrm{a}$ & 112.8 \\
\hline PR 64-1618 & $10.21 \mathrm{a}$ & $31.3 \mathrm{ab}$ & $3.21 \mathrm{a}$ & $10.44 \mathrm{bc}$ & $46.2 \mathrm{a}$ & $4.86 \mathrm{a}$ & $11.63 \mathrm{ab}$ & $46.2 \mathrm{a}$ & $5.35 \mathrm{a}$ & $10.90 \mathrm{bc}$ & $41.1 \mathrm{a}$ & $4.57 \mathrm{a}$ & 121.2 \\
\hline PR $67-245$ & $12.17 \mathrm{a}$ & $30.3 \mathrm{ab}$ & $3.65 \mathrm{a}$ & $12.23 \mathrm{ab}$ & $39.3 \mathrm{bc}$ & $4.79 a$ & $11.53 \mathrm{ab}$ & $43.3 \mathrm{ab}$ & $4.98 \mathrm{ab}$ & $12.13 \mathrm{ab}$ & $37.6 \mathrm{ab}$ & $4.56 \mathrm{a}$ & 120.8 \\
\hline PR 67-3210 & $10.69 \mathrm{a}$ & $28.4 \mathrm{~b}$ & $3.06 \mathrm{a}$ & $12.82 \mathrm{a}$ & $36.8 \mathrm{c}$ & $4.72 \mathrm{a}$ & $14.10 \mathrm{a}$ & $38.7 \mathrm{~b}$ & $5.51 \mathrm{a}$ & $12.62 \mathrm{a}$ & $34.6 \mathrm{~b}$ & $4.50 \mathrm{ab}$ & 119.4 \\
\hline PR 67-1070 & $10.77 \mathrm{a}$ & $33.6 \mathrm{a}$ & $3.60 \mathrm{a}$ & $11.23 \mathrm{abc}$ & $43.7 \mathrm{ab}$ & $4.89 \mathrm{a}$ & $12.01 \mathrm{ab}$ & $41.8 \mathrm{abc}$ & $5.02 \mathrm{ab}$ & $11.22 \mathrm{abc}$ & $39.6 a$ & $4.48 \mathrm{ab}$ & 118.8 \\
\hline PR $67-3073$ & $10.96 \mathrm{a}$ & $31.8 \mathrm{ab}$ & $3.45 \mathrm{a}$ & $12.78 \mathrm{a}$ & $41.3 \mathrm{abc}$ & $5.28 \mathrm{a}$ & $10.77 \mathrm{~b}$ & $35.7 \mathrm{c}$ & $3.84 \mathrm{~b}$ & $11.97 \mathrm{ab}$ & $33.9 \mathrm{~b}$ & $4.45 \mathrm{ab}$ & 118.0 \\
\hline PR 63-192 & $11.33 \mathrm{a}$ & $30.2 \mathrm{ab}$ & $3.47 \mathrm{a}$ & $10.47 \mathrm{bc}$ & $46.7 \mathrm{a}$ & $4.85 a$ & $12.34 \mathrm{ab}$ & 41.2abc & $5.14 \mathrm{ab}$ & $10.88 \mathrm{bc}$ & $39.3 \mathrm{a}$ & $4.38 \mathrm{ab}$ & 116.2 \\
\hline PR 980 & $8.98 \mathrm{a}$ & $27.9 b$ & $2.47 \mathrm{a}$ & $9.58 \mathrm{c}$ & $45.1 \mathrm{a}$ & $4.34 \mathrm{a}$ & $10.26 \mathrm{~b}$ & $47.2 \mathrm{a}$ & $4.62 \mathrm{ab}$ & $9.57 \mathrm{c}$ & $40.6 \mathrm{a}$ & $3.77 \mathrm{~b}$ & 100.0 \\
\hline \multicolumn{14}{|c|}{ Mayo Farm, Humacao } \\
\hline PR 67-3210 & $14.26 \mathrm{a}$ & $48.8 \mathrm{bcd}$ & $6.97 \mathrm{ab}$ & $13.85 a$ & $50.1 \mathrm{ab}$ & $7.03 \mathrm{ab}$ & $11.58 \mathrm{a}$ & $45.2 \mathrm{abc}$ & $5.22 \mathrm{ab}$ & $13.30 \mathrm{a}$ & $48.0 \mathrm{~b}$ & $6.46 \mathrm{a}$ & 127.4 \\
\hline PR $67-3129$ & $14.03 \mathrm{a}$ & $47.7 \mathrm{~cd}$ & $6.69 \mathrm{ab}$ & $12.23 \mathrm{ab}$ & $54.6 \mathrm{ab}$ & $6.69 a b$ & $9.96 \mathrm{a}$ & $49.2 \mathrm{ab}$ & $4.93 \mathrm{ab}$ & $12.05 \mathrm{abc}$ & $50.5 \mathrm{ab}$ & $6.08 \mathrm{a}$ & 119.2 \\
\hline PR 67-3073 & $13.92 \mathrm{ab}$ & $55.0 \mathrm{ab}$ & $7.67 \mathrm{a}$ & $12.88 \mathrm{a}$ & $49.3 \mathrm{~b}$ & $6.32 \mathrm{ab}$ & $11.65 \mathrm{a}$ & $34.4 \mathrm{bcd}$ & $4.06 \mathrm{abc}$ & $12.82 \mathrm{a}$ & $46.2 \mathrm{~b}$ & $6.02 \mathrm{ab}$ & 118.7 \\
\hline PR $67-1070$ & $12.90 \mathrm{abc}$ & $57.0 \mathrm{a}$ & $7.34 \mathrm{ab}$ & $12.89 \mathrm{a}$ & $53.0 \mathrm{ab}$ & $6.86 \mathrm{ab}$ & $9.37 a$ & $41.0 \mathrm{bc}$ & $3.69 \mathrm{bc}$ & $11.72 \mathrm{abc}$ & $50.3 \mathrm{ab}$ & $5.97 \mathrm{ab}$ & 117.8 \\
\hline PR 63-192 & $11.25 \mathrm{c}$ & $54.9 \mathrm{ab}$ & $6.15 \mathrm{bc}$ & $12.54 \mathrm{ab}$ & $59.6 \mathrm{a}$ & $7.45 \mathrm{a}$ & $8.32 \mathrm{a}$ & $50.6 \mathrm{a}$ & $4.33 \mathrm{abc}$ & $10.68 \mathrm{bc}$ & $55.0 \mathrm{a}$ & $5.96 \mathrm{ab}$ & 117.6 \\
\hline PR $67-245$ & $12.44 \mathrm{abc}$ & $54.2 \mathrm{abc}$ & $6.75 \mathrm{abc}$ & $12.19 \mathrm{ab}$ & $55.2 \mathrm{ab}$ & $6.69 \mathrm{ab}$ & $9.56 a$ & $43.4 \mathrm{ab}$ & $4.08 \mathrm{abc}$ & $11.41 \mathrm{bc}$ & $50.9 \mathrm{ab}$ & $5.85 \mathrm{ab}$ & 115.4 \\
\hline H $32-8560$ & $13.41 \mathrm{ab}$ & $42.6 \mathrm{~d}$ & $5.80 c$ & $13.37 \mathrm{a}$ & $49.4 a$ & $6.63 \mathrm{ab}$ & $10.20 \mathrm{a}$ & $29.4 d$ & $2.95 c$ & $12.31 \mathrm{ab}$ & $40.4 \mathrm{c}$ & $5.07 \mathrm{~b}$ & 100.0 \\
\hline PR 64-1618 & $12.12 \mathrm{bc}$ & $47.9 \mathrm{~cd}$ & $5.69 \mathrm{c}$ & $10.69 b$ & $53.8 \mathrm{ab}$ & $5.89 \mathrm{~b}$ & $8.64 a$ & $37.8 \mathrm{c}$ & $3.17 \mathrm{c}$ & $10.54 \mathrm{c}$ & $46.5 \mathrm{~b}$ & $4.94 \mathrm{~b}$ & 97.4 \\
\hline
\end{tabular}




\begin{tabular}{|c|c|c|c|c|c|c|c|c|c|c|c|c|}
\hline \multicolumn{13}{|c|}{ Unión Farm, Yabucoa } \\
\hline PR 67-1070 & $15.30 \mathrm{abc}$ & $53.3 \mathrm{ab}$ & $8.25 \mathrm{a}$ & $12.06 \mathrm{a}$ & $48.6 \mathrm{abc} 5.86 \mathrm{a}$ & $13.39 \mathrm{a}$ & $39.6 \mathrm{a}$ & $5.33 \mathrm{a}$ & $13.58 \mathrm{a}$ & $47.2 \mathrm{a}$ & $6.49 a$ & 147.5 \\
\hline PR 64-1618 & $11.73 \mathrm{ef}$ & $46.4 \mathrm{bc}$ & $5.48 \mathrm{bc}$ & $10.95 a$ & $52.4 \mathrm{ab} \quad 5.66 \mathrm{a}$ & $11.63 \mathrm{~b}$ & $39.4 \mathrm{ab}$ & $4.59 \mathrm{ab}$ & $11.44 \mathrm{~b}$ & $45.9 \mathrm{a}$ & $5.22 \mathrm{~b}$ & 118.6 \\
\hline PR 63-192 & $10.43 \mathrm{f}$ & $44.4 b c$ & $4.68 \mathrm{c}$ & $13.36 \mathrm{a}$ & $43.4 \mathrm{bc} \quad 5.83 \mathrm{a}$ & $12.79 \mathrm{ab}$ & 33.0abcd & $4.15 \mathrm{~b}$ & $12.19 \mathrm{ab}$ & $40.2 \mathrm{ab}$ & $4.88 \mathrm{~b}$ & 110.9 \\
\hline PR 67-3073 & $12.40 \mathrm{cef}$ & $43.4 \mathrm{bc}$ & $5.38 \mathrm{bc}$ & $12.40 \mathrm{a}$ & $42.3 \mathrm{bc} \quad 5.22 \mathrm{a}$ & $11.95 \mathrm{ab}$ & $29.0 \mathrm{bcd}$ & $3.45 \mathrm{bcd}$ & $12.25 \mathrm{a}$ & $38.1 \mathrm{~b}$ & $4.66 \mathrm{~b}$ & 105.9 \\
\hline PR 67-3210 & $14.32 \mathrm{bc}$ & $39.7 \mathrm{c}$ & $5.70 \mathrm{bc}$ & $12.39 a$ & $38.8 \mathrm{c}$ & $13.82 \mathrm{a}$ & $25.4 \mathrm{bcd}$ & $3.57 \mathrm{bcd}$ & $13.51 \mathrm{a}$ & $34.5 \mathrm{~b}$ & $4.64 \mathrm{~b}$ & 105.9 \\
\hline PR 64-610 & $14.24 \mathrm{~cd}$ & $41.8 \mathrm{bc}$ & $5.99 \mathrm{bc}$ & $12.27 \mathrm{a}$ & $38.4 \mathrm{c}$ & $12.90 \mathrm{a}$ & $20.2 d$ & $2.64 \mathrm{c}$ & $13.14 \mathrm{a}$ & $33.4 \mathrm{~b}$ & $4.41 \mathrm{~b}$ & 100.2 \\
\hline PR 1059 & $12.85 \mathrm{de}$ & $38.7 \mathrm{c}$ & $5.00 \mathrm{bc}$ & $13.18 \mathrm{a}$ & $41.5 \mathrm{bc} \quad 5.55 \mathrm{a}$ & $12.81 \mathrm{a}$ & $20.3 \mathrm{~d}$ & $2.62 \mathrm{~cd}$ & $12.95 \mathrm{a}$ & $33.5 \mathrm{~b}$ & $4.40 \mathrm{~b}$ & 100.0 \\
\hline PR 67-3129 & $11.87 \mathrm{ef}$ & $39.9 c$ & $4.73 \mathrm{c}$ & $11.39 \mathrm{a}$ & $42.4 \mathrm{bc} \quad 4.86 \mathrm{a}$ & $11.31 \mathrm{~b}$ & $30.7 \mathrm{~cd}$ & $3.44 \mathrm{bcd}$ & $11.52 \mathrm{~b}$ & $37.5 \mathrm{~b}$ & $4.32 \mathrm{~b}$ & 98.2 \\
\hline
\end{tabular}

1 Tons of cane per acre.

${ }^{2}$ Tons of sugar per acre.

${ }^{3}$ Mean values in the same column followed by one or more letters in common do not differ significantly at the $5 \%$ level.

Unión Farm, Yabuco

$\begin{array}{llllllll}48.6 \mathrm{abc} 5.86 \mathrm{a} & 13.39 \mathrm{a} & 39.6 \mathrm{a} & 5.33 \mathrm{a} & 13.58 \mathrm{a} & 47.2 \mathrm{a} & 6.49 \mathrm{a} & 147.5\end{array}$

$\begin{array}{lllllllll}52.4 \mathrm{ab} & 5.66 \mathrm{a} & 11.63 \mathrm{~b} & 39.4 \mathrm{ab} & 4.59 \mathrm{ab} & 11.44 \mathrm{~b} & 45.9 \mathrm{a} & 5.22 \mathrm{~b} & 118.6\end{array}$

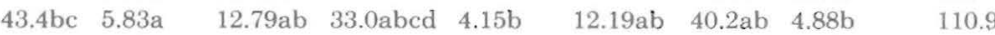



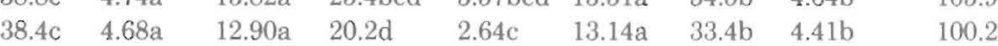

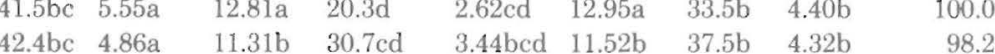




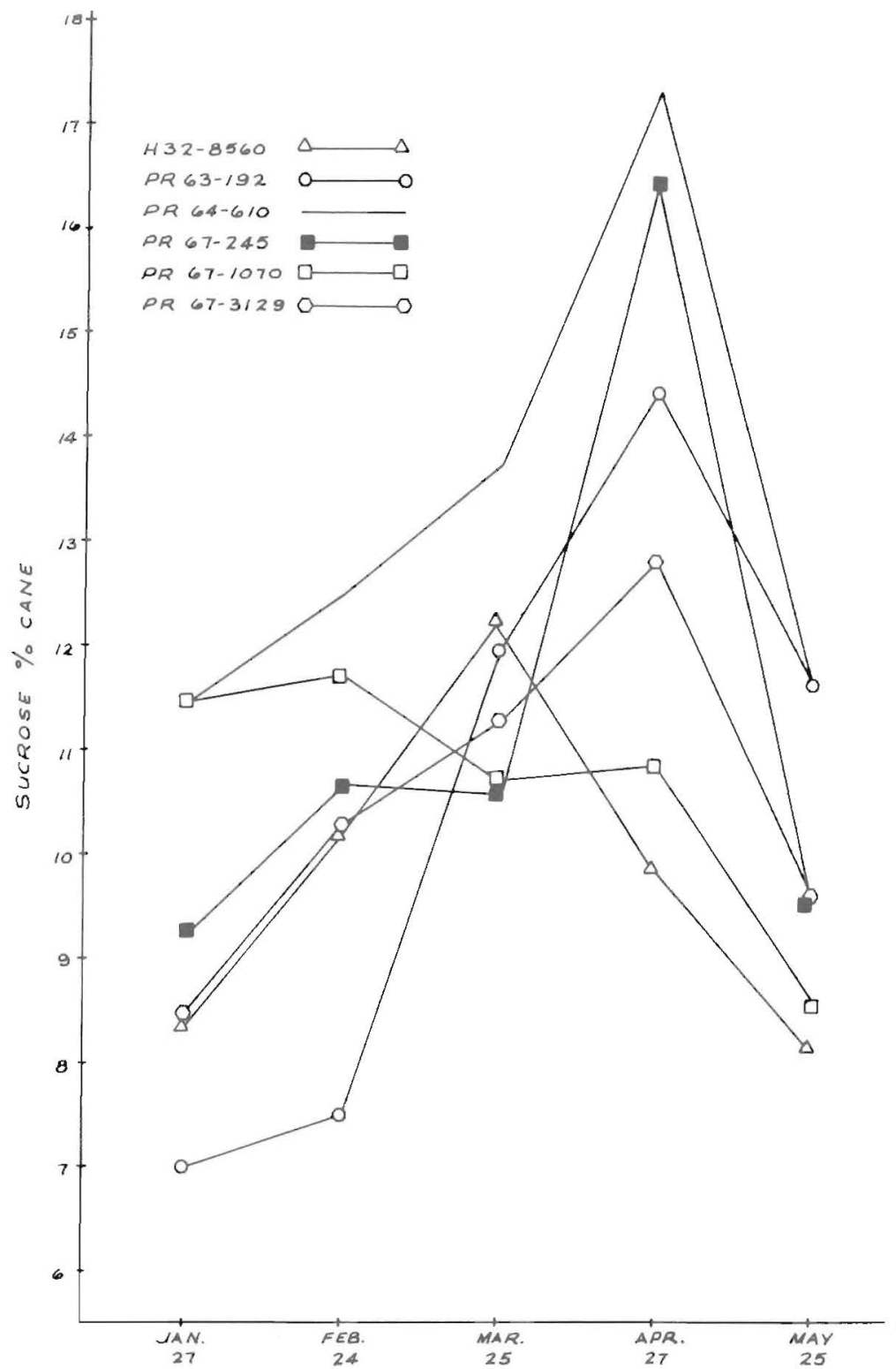

FIG. 1.-Relative maturity pattern in plant cane of six varieties grown at Mayo Farm, Humacao.

sugar per acre than the standard variety $\mathrm{H}$ 32-8560. They surpassed variety $\mathrm{H} 32-8560$ by values of 27.4 and $19.2 \%$, respectively. No significant difference was observed among the other varieties.

Results from Unión Farm, Yabucoa (table 3) revealed that variety PR 


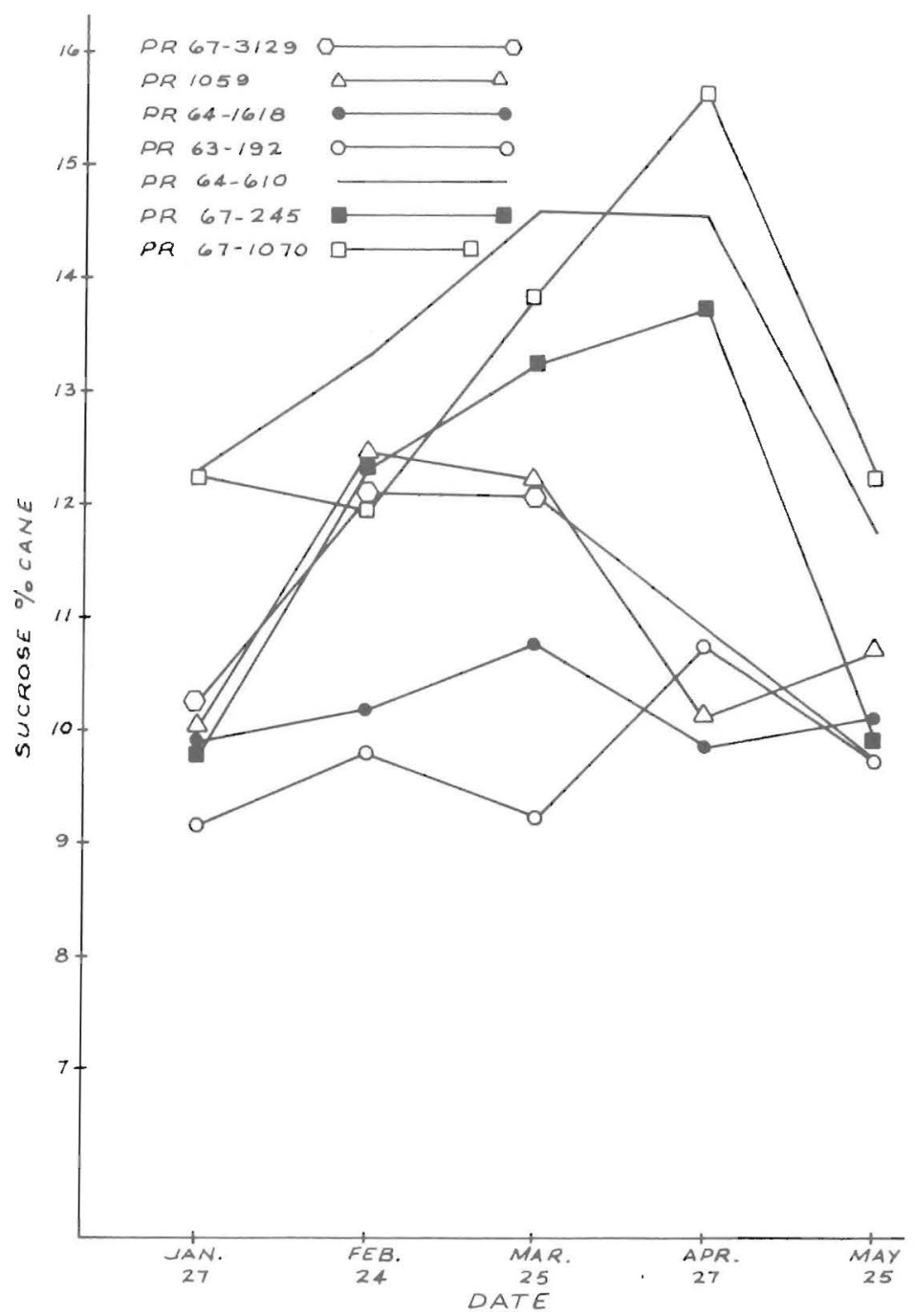

FIG. 2.-Relative maturity pattern in plant cane of seven varieties grown at Isleta Farm, Yabucoa.

67-1070 gave a higher yield of both tons of cane per acre and tons of sugar per acre in the combined analysis of three crops. It outyielded the standard commercial variety, PR 1059, by $47.5 \%$ in tons of sugar per acre. Moreover, PR 67-1070 produced significantly higher TSA values than any other variety being evaluated.

With reference to season of maturity, variety PR 64-610 produced the highest sucrose-percent-cane values at nearly all sampling dates from January 27 to May 25 (fig. 1). Its peak value, attained on April 27, was 
17.30\%. Variety PR 67-1070 showed a rapidly rising trend during January and February but declined steadily thereafter. In marked contrast, the sucrose-percent-cane figures for PR 63-192 were extremely low in January but rose sharply in March and reached their peak in April. Variety H 328560 attained its peak in March while PR 67-245 and PR 67-3129 gave their best yields in April.

Seasonal trends somewhat similar to those at Mayo Farm were again observed at Isleta Farm (fig. 2). Both PR 64-610 and PR 67-1070 revealed high juice quality at almost all sampling dates. Peaks were attained in March (14.60\%) for PR 64-610, and in April (15.66\%) for PR 67-1070. Varieties PR 67-3129 and PR 1059 showed a somewhat identical maturity pattern with peak values appearing in February. PR 67-245 peaked in April, and was ranked third relative to juice quality. Relatively low and level maturity patterns were observed for varieties PR 64-1618 and PR 63-192. Under conditions prevailing in the Yabucoa area, varieties PR 64-610, PR 67-1070, and PR 67-245 appear to mature at mid-to-lateseason, while PR 67-3129 and PR 1059 are early- to mid-season varieties.

\section{DISCUSSION*}

Results from the 1973-77 trials were encouraging and suggest that important progress has been made in combining high sucrose content with high yield and other desirable characters.

Variety PR 67-1070 is a promising candidate for Puerto Rico's eastern coastal plains. It is a good germinator with good tillering, and produces rather thick stalks having good drought tolerance and lodging resistance (table 2). It was obtained from a polycross of $\mathrm{H}$ 32-8560. During these investigations, PR 67-1070 either led other varieties or was persistently in the top group. It performed exceptionally well in the light soil at Unión Farm in Yabucoa, where its high production of sugar per acre derived both from a high sucrose content and a high tonnage of stalks (table 3 ). Its high juice quality was also evidenced in the maturity study (fig. 2).

With no appreciable differences observed in the rainfall distribution pattern at the four test sites (fig. 3), the marked superiority of PR 671070 at Unión Farm is presumably attributable to the soils. This observation suggests that in the east coastal plain of Puerto Rico, PR 67-1070

* Editor's Note:

When the article was already in galley stage, the author submitted the following additional information:

PR 67-3129 was found to be highly susceptible to sugarcane rust (Puccinia erianth) which was detected in Puerto Rico in October 1978. The recommendation that PR 67-3129 be tried in commercial plantings is no longer valid. PR 67-1070, PR 67-245, and PR 64-1618 were highly resistant to rust under commercial field conditions in spite of the presence of high incidence of the disease. 


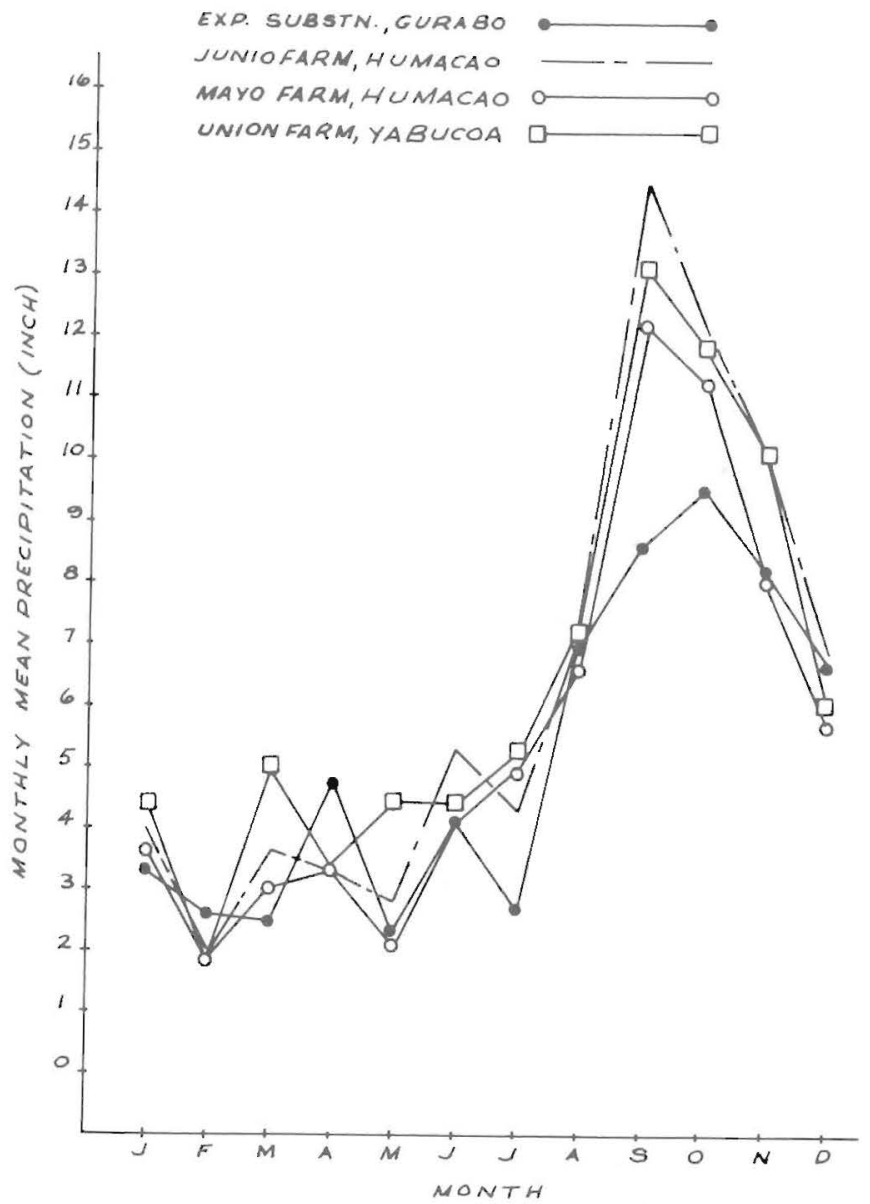

FIG. 3.-Distribution of mean monthly precipitation of the years 1974, 1975, and 1976 at four experimental sites.

is the variety best suited to the area's highly-permeable and well-drained soil. Its tendency of rapidly rising in sucrose-percent-cane in January and February (figs. 1 and 2) suggests that it would accommodate early harvest schedules at both Humacao and Yabucoa. Its best harvest period in the Yabucoa region appears to be in March and April.

PR 67-3129, with NCo 310 as its pistil parent crossed with PR 1047, gave better performance at two test sites having soils classified as Mabí clay and Maunabo clay. This variety is characterized by good germination, heavy tillering, and very good ratooning ability, features apparently inherited from NCo 310. Its high average production of sugar per acre was apparently due to its good ratooning ability (table 3 ). As far as its 
juice quality is concerned, PR 67-3129 clearly exceeded PR 980 (table 3). It was similar to $\mathrm{H} 32-8560$ at Mayo Farm (fig. 1) and to PR 1059 at Isleta Farm (fig. 2). Its optimum harvest season appears to be March and April around Humacao, and February and March for the Yabucoa area.

PR 67-245 (H 49-134 x Co 775) is a variety with rather thick stalks, a heavy tillering habit, and is highly resistant to lodging (table 2). This variety performed well in the heavy soils at two test sites in the Humacao area (table 3 ). Its erectness and uniform cane height favor mechanized harvest. In addition to a reasonably good TCA production, PR 67-245 produced high juice quality when harvested in March and April.

PR 64-1618, obtained from a polycross of PR 1028, is a high yielding and good ratooning variety as evidenced by results from two experiments (table 3). Owing to its rapid growth habit, wide range of adaptability, high cane tonnage, and suitability for mechanized harvest, the acreage of PR 64-1618 is expected to be expanded in this area.

PR 63-192 (PR 1070 x B 34104) is characterized by slow-growth, heavy tillering, good ratooning ability, and is highly resistant to lodging. On the basis of the sucrose-percent-cane values obtained from nine crops in three experiments, PR 63-192 (like PR 64-1618) appears to have poor juice quality when harvested early. It can be a good sugar producer when harvested late in the season under Humacao conditions (fig. 1).

PR 64-610 (Co $421 \times$ POJ 2878) had very high juice quality and produced high cane tonnage in the plant cane, but dropped significantly in the second ratoon crop (table 3). It was also susceptible to drought injury and lodging (table 2). These features would probably disqualify PR 64-610 as a commercial variety in this region.

PR 67-3210 (PR $1013 \times$ PR 1059) is thin-stalked and has good juice quality plus a high resistance to lodging. During these trials it performed much like its male parent, PR 1059. It requires further evaluation under Humacao conditions.

PR 67-3073 (PR $1062 \times \mathrm{H} \mathrm{41-3340)} \mathrm{is} \mathrm{a} \mathrm{thick-stalked} \mathrm{variety} \mathrm{with} \mathrm{a}$ reasonably good cane tonnage and good juice quality. However, because of its susceptibility to lodging, PR 67-3073 is not suitable for mechanized harvest.

\section{RESUMEN}

Treinta y siete nuevas variedades de caña de azúcar se evaluaron en cuatro experimentos en los llanos costeros e interiores de la región oriental de Puerto Rico durante los años 1973-77.

Los resultados de las cosechas de plantilla y dos retoños demostraron ser altamente satisfactorios.

La variedad PR 67-1070 produce cañas gruesas, es buena germinadora y retonadora y es tolerante a la sequía y al encamado. Es la mejor de todas las variedades probadas por su producción en toneladas de caña y alto rendimiento en azúcar. Parece ser apta para los suelos permeables y de buen drenaje de la región de Humacao-Yabucoa. Su alto contenido en sacarosa durante los meses de enero y febrero la hacen recomendable para comenzar la zafra en toda esta área; no obstante, en Yabucoa alcanza la maduración máxima en abril. 
La variedad PR 67-3129 que produce buen tonelaje, y es buena germinadora, ahijadora y retonadora parece ser más apta para los suelos húmedos y pesados de esta región. Su más elevado contenido en azúcar se logra aparentemente en abril en Humacao, y en febreromarzo en Yabucoa.

La variedad PR 67-245, de cañas más bien gruesas, es buena ahijadora y resistente al encamado. Se adapta bien a los suelos pesados de la región. Su máxima maduración ocurre en abril.

La variedad PR 64-1618 es de rápido crecimiento inicial, buena retoñadora, resistente al encamado y de una alta producción en toneladas de caña. Su contenido en sacarosa no es alto.

La variedad PR 63-192 produce buen tonelaje en los suelos pesados ya mencionados. Se caracteriza por un crecimiento inicial lento, buen ahijamiento, retoñamiento y alta resistencia al encamado. Por los datos de maduración estudiados es recomendable sembrarla para cosecharla en abril.

Las variedades PR 64-610 y la PR 67-3073, aunque producen un alto tonelaje y sus jugos son de buena calidad, no son aptas para el corte mecanizado, por su peculiar hábito de crecimiento.

La variedad PR 67-3210, de cañas delgadas, erguida y buena productora de sacarosa, debe observarse más detenidamente en la zona de Humacao, a causa de la inconsistencia de los datos obtenidos. 